\title{
A QUESTÃO DA JUSTA INDENIZAÇÃO NAS AÇÕES DE DESAPROPRIAÇÃO POR UTILIDADE PÚBLICA (MEGAEVENTOS ESPORTIVOS)
}

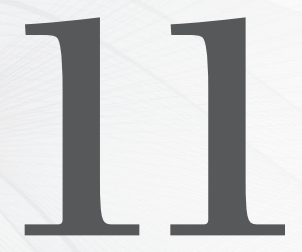

\author{
Uma discussão a partir do direito \\ fundamental à moradia, do direito à cidade \\ e do princípio da dignidade humana
}

A question of just compensation in shares of expropriation by public utility (sporting huge event): a discussion from the fundamental right to housing, the right to the city and the principle of human dignity

\section{Marise Costa de Souza Duarte}

Doutora em Urbanismo (estágio de doutoramento na Faculdade de Direito da Universidade de Coimbra, Portugal) e Mestre em Direito Público pela UFRN. Professora em cursos de Pós-graduação da UFRN e da Universidade Potiguar. Membro da Diretoria do Ibap e da Aprodab. Procuradora do Município de Natal/RN.

\section{Ricardo DuARTE JR.}

Especialista em Direito Administrativo e Mestrando em Direito Constitucional pela UFRN. Pós-graduando em Direito Constitucional e Tributário pela Universidade Potiguar (UnP). Professor de Direito Administrativo na Faculdade Natalense de Ensino e Cultura (Fanec) e na Faculdade de Ciência, Cultura e Extensão do Rio Grande do Norte (Facex). Membro da Comissão de Estudos Constitucionais da OAB-RN. Advogado. 
Resumo: 0 trabalho pretende colocar em pauta uma discussão sobre o requisito da justa indenização nas ações de desapropriação por utilidade pública, no caso da população de interesse social (de 0 a 3 salários mínimos), considerando o regime jurídico que ampara o direito fundamental à moradia e o direito à cidade. Problematizando esse tema, busca-se inicialmente expor o regime jurídico que fundamenta o direito à moradia e o direito à cidade; procedendo-se em seguida uma abordagem sobre o instituto da desapropriação em face tanto do domínio quanto da posse - em seus elementos centrais (onde se coloca o requisito da justa indenização), enfocando-se o tratamento da doutrina e da jurisprudência sobre a questão e colocando em pauta o novo tratamento ao direito fundamental à moradia posto na Constituição Federal de 1988 e o marco regulatório do direito à cidade, com foco na população de interesse social. Tratando da inaplicabilidade do Dec.-lei 3.365/1941 em face da Carta Magna de 1988 e o Estatuto da Cidade (Lei 10.257/2001), a discussão traz o foco para o contexto dos megaeventos esportivos (Copa do Mundo - 2014 e Olimpíadas - 2016), onde o Estado - ente que tem o dever objetivo de concretizar/efetivar o direito fundamental à moradia - não visualiza a situação de vulnerabilidade de uma população de interesse social, para a qual, em razão de sua exclusão do acesso ao mercado imobiliário formal, o conceito de justa indenização deve ser visto de forma ampliada, relacionando-se, de maneira intrinseca, com o direito à moradia (art. 6. ${ }^{\circ}$, caput, da CF/1988, com o direito à cidade posto legalmente no Estatuto da Cidade (Lei 10.257/2001) e com o princípio da dignidade da pessoa humana (art.1. ․ III, da CF/1988).

Palavras-chave: Justa indenização - Desapropriação por utilidade pública - Direito fundamental à moradia - Direito à cidade - Princípio da dignidade da pessoa humana.
ABSTRACT: This paper pretends to put under discussion the requirement of just compensation on Condemnation by public utility, in the case of population of social interest (from 0 to 3 minimum wage), considering law system that protects fundamental rights to habitation and to city. Problematizing, first we want to demonstrate law system that justify the right to habitation and to city; after we talk about the main aspects of expropriation's institute, giving priority to how doctrine and jurisprudence deal it and putting under discussion new treatment to fundamental right to habitation on Federal Constitution from 1988 and regulatory framework of right to habitation, focusing on interest social population. Dealing with the inapplicability of the Executive order 3.365/1941 by Federal Constitution from 1988 and the City Statute (Federal Law 10.257/2001), discussion brings focus to the context of sports megaevents (Word Cup - 2014 and Olympics Games - 2016), in which the State - who should implement the fundamental rights - do not see the vulnerability of interest social population, for which, because of their exclusion from access to formal housing market, the concept of just compensation should be seen in a broad way, relating to fundamental right to habitation (art. 6. ${ }^{\circ}$ from Federal Constitution and City Statute anda the principle of human dignity.

KEYWORDS: Just compensation - EXpropriation by public utility - Fundamental right to habitation Right to city - Principle to human dignity.

SUMÁRIO: 1. Introdução - 2. 0 direito à moradia e seu regime jurídico de proteção e o direito à cidade - 3. Aspectos gerais do instituto da desapropriação - 4. Da desapropriação da posse: uma possibilidade em nosso sistema jurídico - 5. A justa indenização: da insuficiência do critério estritamente monetário - 6. Uma nova e necessária visão da desapropriação por utilidade pública (em megaeventos esportivos) e a inaplicabilidade do Dec.-lei 3.365/1941 - 7. Conclusão - 8. Referências. 


\section{INTRODUÇÃO}

Sabemos que a evolução e a dialética da realidade social provocam o Direito a rever seus conceitos e seus institutos. Por não ser uma ciência estática e descolada da sociedade, mas, ao contrário, vindo regular essa mesma realidade, tendo a prevalência dos direitos fundamentais e princípios correlatos em sua base, cabe ao Direito no enfrentamento dessa realidade visualizar novas ideias, novas concepções, novas teorias.

É a partir dessa compreensão que foi constituído esse texto.

Considerando um (importante) fato social - a realização de megaeventos esportivos nas cidades brasileiras - e visualizando as consequências que esse fato pode trazer na efetivação do direito fundamental à moradia, no direito à cidade e no princípio da dignidade da pessoa humana que ampara a população urbana, especialmente a de mais baixa renda, é que foi necessário rever algumas questões referentes à desapropriação por utilidade pública, prática que se intensificará nas cidades brasileiras a partir da necessidade de viabilizar projetos e obras voltadas àqueles eventos.

Em um contexto em que é o Poder Público o grande viabilizador dos megaeventos esportivos, que, embora de natureza privada, possuem total dependência das verbas públicas, é que se faz - mais do que necessário - discutir as questões postas neste estudo, onde a compreensão do termo justa indenização possa ultrapassar apenas o viés monetário, mas venha incorporar as noções dos direitos que se efetivam nas cidades e que suscitam deveres incontestáveis ao Poder Público; tudo com amparo no substancioso regime jurídico dos direitos fundamentais, que possui expressão concreta na Constituição Federal de 1988 e na legislação infraconstitucional, se destacando in casu o Estatuto da Cidade.

\section{O DIREITO À MORADIA E SEU REGIME JURÍDICO dE PROTEÇÃO E O DIREITO À CIDADE}

Muito falamos sobre o direito à moradia. Porém, por vezes nos esquecemos de dar a devida atenção ao forte suporte jurídico que o mesmo possui e que possibilita uma outra abordagem sobre o seu resguardo, notadamente em uma época (de preparação das cidades para os megaeventos esportivos) onde não raro se ignora absolutamente esse direito fundamental especialmente das pessoas de baixa renda, aqui compreendida como a população de interesse social (de 0 a 3 salários mínimos). 
Inicialmente registra-se que na trilha da proteção posta em nível internacional, a moradia (inegavelmente) ${ }^{1}$ passou, no sistema jurídico brasileiro, a possuir status de direito humano fundamental (tendo como essência o princípio da dignidade humana) por força da EC 26, de 14.02.2000, que inseriu aquele direito no rol dos direitos sociais ${ }^{2}$ contidos no art. $6 .^{\circ}$, Título II (Dos direitos e garantias fundamentais); compondo, portanto, o quadro de direitos fundamentais constante no ordenamento brasileiro.

Mas o que se quer dizer quando se afirma que a moradia se constitui, hoje, um direito fundamental no sistema jurídico brasileiro? E quais as implicações disso quando nos deparamos com ações do Poder Público que parecem ignorar completamente esse preceito?

Podemos dizer que a implicação essencial consiste no fato de que o direito à moradia se coloca regido por um regime jurídico especial, que, em última análise, impede que pessoas sejam despojadas sumariamente de seus locais de moradia. Vejamos, juridicamente, como e porque isso ocorre. ${ }^{3}$

Os direitos fundamentais são concebidos sob duas dimensões, quais sejam: de direito subjetivo e de dever objetivo; que suscitam uma relação de correspondência.

Como direito subjetivo, os direitos fundamentais se apresentam sob uma perspectiva individual (aplicável a pessoas individualmente consideradas ou a grupos), suscitando o reconhecimento de posições jurídicas aos titulares do direito, ${ }^{4}$ no sentido de determinado grau de exigibilidade (ou justicialidade).

1. Destaca-se entendimento de Ingo Sarlet no sentido de que, mesmo antes da vigência dessa emenda constitucional, o direito à moradia já se encontrava posto no texto constitucional, de forma expressa ou implícita; sendo decorrência do princípio da dignidade da pessoa humana (art.1. ${ }^{\circ}$, III, da CF/1988) vez que este reclama, na sua dimensão positiva, a satisfação das necessidades existenciais básicas para uma vida com dignidade, podendo servir até mesmo como fundamento direto e autônomo para o reconhecimento de direitos fundamentais não expressamente positivados, mas inequivocamente destinados à proteção da dignidade. O direito fundamental à moradia na Constituição: algumas anotações a respeito de seu contexto, conteúdo, e possível eficácia. Revista Eletrônica sobre a Reforma do Estado (RERE) 20/12.

2. Juntamente com os direitos à educação, à saúde, ao trabalho, ao lazer, à segurança, à previdência social, à proteção à maternidade e à infância e assistência aos desamparados.

3. Ampla abordagem dessa matéria pode ser encontrada em DuARTE, Marise Costa de Souza. Espaços especiais em Natal (meio ambiente e moradia): um necessário diálogo entre direitos e espaços na perspectiva de proteção aos direitos fundamentais na cidade contemporânea. Tese de Doutorado em Arquitetura e Urbanismo, Natal. UFRN, 2010.

4. Nos termos postos por Canotilho um direito subjetivo fundamental "é a posição jurídica pertencente ou garantida a qualquer pessoa com base numa norma de direitos 
Trazendo à tona o conceito de direito subjetivo integrante da teoria geral do direito, ${ }^{5}$ Luis Roberto Barroso ${ }^{6}$ destaca que as normas constitucionais definidoras de direitos (direitos subjetivos constitucionais) "investem seus destinatários em situações jurídicas imediatamente desfrutáveis, a serem efetivadas por prestações positivas ou negativas, exigíveis do Estado ou de outro destinatário da norma". Assim, pode-se dizer que os direitos fundamentais têm por objetivo "conferir aos indivíduos uma posição jurídica de direito subjetivo, em sua maioria de natureza material, mas às vezes de natureza processual e, consequentemente, limitar a liberdade de atuação dos órgãos do Estado". ${ }^{7}$ Desse modo, para Sarlet, ${ }^{8}$ quando se fala nessa perspectiva subjetiva, nos referimos à possibilidade que tem o titular do direito (pessoa individual ou ente coletivo) de "fazer valer juridicamente os poderes, liberdades ou mesmo o direito à ação ou às ações negativas ou positivas que lhe foram outorgadas pela norma consagradora do direito fundamental em questão".

Nesse contexto, relevante é o entendimento do Vasco Pereira da Silva ${ }^{9}$ no sentido de que o reconhecimento dos direitos fundamentais implica o equilíbrio das relações relativas entre o Estado e o cidadão, fazendo com que o individuo deixe de ser tratado como objeto do poder e passe de "súdito" a "cidadão"; transformando-se em sujeito de direito, em condições de estabelecer relações jurídicas com a Administração. Assim, o individuo titular de direitos

fundamentais consagrada na Constituição". Tomemos a sério os direitos econômicos, sociais e culturais. Coimbra: Coimbra Ed., 2004. p. 184.

5. Ensina Barroso, de modo abreviado, que por direito subjetivo se entende o poder de ação, assente no direito objetivo, e destinado à satisfação de um interesse; tendo as seguintes características essenciais: "(a) a ele corresponder sempre um dever jurídico por parte de outrem; (b) ele é violável, vale dizer, pode ocorrer que a parte que tem o dever jurídico, que deveria entregar uma determinada prestação, não o faça; (c) violado o dever jurídico, nasce para o seu titular uma pretensão, podendo ele servir-se dos mecanismos coercitivos e sancionatórios do Estado, notadamente por via de uma ação judicial". O direito constitucional e a efetividade de suas normas: limites e possibilidades da Constituição brasileira. 9. ed. Rio de Janeiro: Renovar, 2009. p. 303.

6. Op. cit., p. 303.

7. Dimoulis, Dimitri; Martins, Leonardo. Teoria geral dos direitos fundamentais. 2. ed. São Paulo: Ed. RT, 2008. p. 54.

8. A eficácia dos direitos fundamentais. Porto Alegre: Livraria do Advogado, 1998. p. 152.

9. Em busca do acto administrativo perdido. reimpr. Coimbra: Livraria Almedina, 1998. Dissertação de Doutoramento em Ciências Jurídico-Políticas na Faculdade de Direito da Universidade Católica Portuguesa. p. 212. 
fundamentais, segundo o autor, não guarda relação de subalternidade perante a Administração, mas o permite ser tratado "de igual para igual". Considerando que esse reconhecimento de titularidade de direitos subjetivos diante das autoridades públicas se constitui uma projeção jurídica da dignidade da pessoa humana, o autor entende que o mesmo se constitui um princípio essencial do Estado de Direito, que vai importar em consequências práticas no âmbito do direito administrativo. ${ }^{10}$ Desse modo, para esse autor:

"O reconhecimento de direitos subjetivos públicos não é uma simples posição teórica, ou uma mera petição de princípios, antes uma posição jurídica com consequências decisivas para todo o domínio público-administrativo."11

Por outro lado, na perspectiva jurídico-objetiva ${ }^{12}$ (ou na dimensão dos direitos fundamentais como dever objetivo), coloca-se a ideia da vinculação estatal às normas de direito fundamental postas na ordem constitucional. Nessa perspectiva, tais direitos "constituem decisões valorativas de natureza jurídico-objetiva da Constituição, com eficácia em todo o ordenamento jurídico e que fornecem diretrizes para os órgãos legislativos, judiciários e executivos". ${ }^{13}$ Isso traduz a ideia central de que ao lado dos direitos subjetivos que comportam os direitos fundamentais encontram-se deveres fundamentais do Estado na con-

10. Idem, p. 213.

11. Idem, ibidem.

12. Sarlet afirma que a perspectiva jurídico-objetiva dos direitos fundamentais teve como impulso decisivo a Constituição de Bohn, de 1949. E ainda: o caso Lüth, julgado pelo Corte Federal Constitucional alemã foi um marco na defesa dessa perspectiva, pois afirmou no sentido de que "os direitos fundamentais não se limitavam à função precípua de serem direitos subjetivos de defesa do indivíduo contra atos do Poder Público, mas que, além disso, constituem decisões valorativas de natureza jurídico-objetiva da Constituição, com eficácia em todo o ordenamento jurídico e que fornecem diretrizes para os órgãos legislativos, judiciários e executivos. Em outras palavras, (...), os direitos fundamentais passaram a apresentar-se no âmbito da ordem constitucional como um conjunto de valores objetivos básicos e fins diretivos da ação positiva dos Poderes Públicos, e não apenas garantias negativas dos interesses individuais". A eficácia dos direitos fundamentais cit., p. 140.

13. Nessa análise, o autor destaca o entendimento de Pérez Luno segundo o qual "os direitos fundamentais passaram a apresentar-se no âmbito da ordem constitucional como um conjunto de valores objetivos básicos e fins diretivos da ação positiva dos Poderes Públicos, e não apenas garantias negativas dos interesses individuais", posição consagrada pelo Tribunal Constitucional Espanhol. SArLet, Ingo Wolfgang. A eficácia dos direitos fundamentais cit., p. 140. 
cretização desses direitos. ${ }^{14}$ Ou seja, aquilo que para o cidadão constitui um direito, para o Estado constitui uma obrigação. Assim, os direitos fundamentais consistem numa relação de direitos públicos subjetivos de pessoas (cidadãos e pessoa jurídica) e coletividade oponíveis em face do Estado (eficácia vertical ${ }^{15}$ dos direitos fundamentais); constituindo uma relação de correspondência direito subjetivo $\leftrightarrow$ dever objetivo estatal.

Constituindo-se numa evolução normativa quanto à proteção ao direito de moradia, o regramento contido no Estatuto da Cidade veio conceder as bases para a sua efetivação/concretização no meio urbano, prevendo uma série de diretrizes e instrumentos, e tratando expressamente da gestão democrática da cidade como forma da viabilização daquele dever estatal. ${ }^{16}$

Importa considerar que a inclusão do capítulo da política urbana e do direito à moradia na Constituição Federal, assim como a edição do Estatuto da Cidade (que passou a possibilitar a efetivação/concretização das normas constitucionais) e da MedProv 2.220/2001, não se deram como dádiva do Estado, mas foram "decorrentes da intensa mobilização popular em torno de uma cidade mais justa e politicamente democrática, que se tornou conhecida como o movimento pelo direito à cidade". ${ }^{17}$

Diante desses avanços conquistados, é valioso o pensamento de Saule Jr. ${ }^{18-19}$ no que se refere à obrigação do Estado Brasileiro em "impedir a regressivi-

14. Nessa mesma trilha, também são as lições de Fernando Alves Correia para quem os direitos fundamentais são entendidos como direitos subjetivos e como princípios objetivos da ordem constitucional. Os direitos fundamentais e sua proteção jurisdicional efectiva. Boletim da Faculdade de Direito da Universidade de Coimbra LXXIX/68.

15. Atualmente, fala-se também em eficácia horizontal dos direitos fundamentais; ou seja, quando tais direitos são oponíveis contra os próprios cidadãos.

16. Nessa mesma trilha, veio a MedProv 2.220, de 04.09.2001, na qual foi reconhecido expressamente o direito de ocupantes de baixa renda ao direito de moradia, através do instrumento da concessão de uso especial, desde que atendidos os requisitos legais ali estabelecidos.

17. Ferreira, João Sette Whitaker; Motisuke, Daniela. A efetividade da implementação de zonas especiais de interesse social no quadro habitacional brasileiro: uma avaliação inicial. In: Bueno, Laura Machado de Mello; Cymbalista, Renato (orgs.). Planos diretores municipais: novos conceitos de planejamento territorial. São Paulo: Annablume, 2007. p. 43.

18. SAULE JR., Nelson. O direito à moradia como responsabilidade do Estado brasileiro. In: (org.). Direito à cidade: trilhas legais para o direito à cidades sustentáveis. São Paulo: Max Limonad, 1999. p. 123.

19. Observa-se que o autor assim já entendia mesmo antes do direito à moradia ser posto como direito fundamental na Carta Magna, mas tão somente a partir das normas internacionais incidentes. 
dade do direito à moradia e de impedir medidas e ações que dificultem ou impossibilitem o exercício do direito à moradia". Para o mesmo doutrinador, também se constitui como efeito da obrigação do Estado brasileiro, no sentido da promoção e proteção do direito à moradia, a intervenção e regulamentação das atividades do setor privado no tocante à política habitacional, como a regulamentação do uso e acesso à propriedade imobiliária, especialmente a urbana (no sentido do atendimento ao princípio da função social da propriedade), a regulamentação do mercado de terra, a criação de sistemas de financiamento de habitação de interesse social e a regulamentação e disposição sobre o uso do solo urbano e sobre o direito de construir. ${ }^{20}$ Todas essas medidas se colocam como deveres objetivos estatais (inarredáveis) no sentido da efetivação/concretização do direito fundamental à moradia.

Para os municípios brasileiros, com fundamento no regramento constitucional e no Estatuto da Cidade, se evidenciam a obrigação de constituir um sistema municipal de habitação e de instituir, em seus planos diretores, instrumentos voltados a efetivar o direito à cidade, através dos quais possa se efetivar/concretizar o direito à moradia da população em estado de pobreza e miséria. Através dos planos diretores, são adotados e aplicados vários instrumentos voltados a esse fim, dentre os quais se incluem as zonas especiais de interesse social; ${ }^{21}$ que passam a se colocar como instrumentos de efetivação/ concretização do direito à moradia, em nível local, adotados no âmbito da atividade estatal de planejamento urbano e gestão urbana.

Nesse contexto, destaca-se que as discussões integradas sobre a efetividade desse direito na sociedade contemporânea, essencialmente urbana, trazem à tona a perspectiva do direito à cidade a ser entendido também como direito fundamental.

A discussão sobre o direito à cidade foi introduzida, gradativamente, nos fóruns internacionais urbanos e na pauta dos processos globais voltados a tratar dos assentamentos humanos, cabendo destacar o Tratado sobre a questão urbana, denominado "Por Cidades, Vilas e Povoados Justos, Democráticos e Sustentáveis", elaborado na Conferência da Sociedade Civil sobre Meio Ambiente e Desenvolvimento, durante a Conferência do Rio (1992) e durante a mencionada Conferência das Nações Unidas sobre Assentamentos Humanos - Habitat II. ${ }^{22}$

20. SaUle JR., Nelson.Op. cit., p. 123.

21. Idem, p. 124.

22. Como lembra Saule Jr. O direito à cidade como condição para cidades justas, humanas e democráticas. 2005. Disponível em: [www.polis.org.br]. Acesso em: 07.07.2008. 
Sendo objeto de discussões travadas no Fórum Social Mundial, desde 2001, a ideia de internacionalização do direito à cidade vem, cada vez mais, adquirindo consistência. O principal objetivo da elaboração de uma Carta Mundial do Direito à Cidade é disseminar a concepção do direito à cidade como um novo direito humano com base numa plataforma de reforma urbana a ser implementada pelos países, visando a modificar a realidade urbana mundial mediante a construção de cidades justas, humanas, democráticas e sustentáveis; associado ao seu reconhecimento institucional nos organismos internacionais. ${ }^{23}$

Sob essa compreensão, podemos dizer que o direito à cidade, ${ }^{24}$ hoje objeto de amplo reconhecimento em fóruns internacionais, e que no Brasil tomou a denominação de direito à cidade sustentável (nos termos do art. 2. ${ }^{\circ}$, I, do Estatuto da Cidade), veio possibilitar uma visão integrada com o direito à moradia, que precisa ser obrigatoriamente considerada quando se trata do seu regime jurídico de proteção. Sob outra ótica, o direito à moradia digna e adequada não significa apenas o acesso a uma unidade habitacional, mas o acesso a todos os benefícios públicos que a cidade oferece a seus habitantes, independente de sua classe social.

Disso tudo decorre que os entes estatais (especialmente os municípios), através de suas esferas de poder, na realização de suas ações (incluindo-se a aprovação das leis e viabilização de projetos voltados à preparação das cidades para os megaeventos esportivos) devem não só respeitar o regime jurídico de proteção ao direito à moradia (especialmente das pessoas de baixa renda) e ao direito à cidade, mas cumprir seu dever objetivo de efetivar/concretizar tais normas.

\section{ASPECTOS GERAIS DO INSTITUTO DA DESAPROPRIAÇÃO}

No âmbito da perspectiva objetiva do direito fundamental à moradia, como já visto, se coloca o dever do Poder Público de efetivação/concretização desse direito; que deve ser observado em todas as ações e atuações estatais que o envolvam. Nesse sentido, podemos afirmar, desde o início, que no âmbito do procedimento da desapropriação há que ser observado todo o regime jurídico que ampara o direito fundamental à moradia e o direito à cidade, especialmente quando se trata da população de interesse social (que, sem acesso ao mercado imobiliário, se encontra na dependência absoluta das ações estatais).

23. Tratamos dessa matéria em artigo publicado no ano de 2009, colacionado nas referências bibliográficas desta obra.

24. Que pode ser tido como direito materialmente constitucional, fundamentado no art. $5 .^{\circ}, \S 2 .^{\circ}$, da $\mathrm{CF} / 1988$. 
A princípio, importa considerar que a desapropriação se constitui uma das formas através das quais o Estado intervém na propriedade privada, tendo em vista a satisfação de interesses públicos. Assim, sob os ditames legais e com base no princípio da supremacia do interesse público sobre o privado ${ }^{25}$ o Estado intervém na propriedade do particular com o fito de adequá-la ou condicioná-la à sua função social.

Desse modo, apesar de o direito de propriedade ser previsto em nosso ordenamento jurídico, sendo assegurado ao seu titular o poder de usar, gozar, usufruir, dispor e reaver o bem, de modo absoluto, exclusivo e perpétuo, esse direito obrigatoriamente se vincula à sua função social, com fundamento no art. 5. ${ }^{\circ}$, XXII e XXIII, da CF/1988.

Quanto à função social da propriedade, podemos colacionar as seguintes posições doutrinárias:

"A função social se manifesta na própria configuração estrutural do direito de propriedade, pondo-se concretamente como elemento qualificante na predeterminação dos modos de aquisição, gozo e utilização dos bens." 26

"A função social da propriedade, consubstanciada no dever de que a propriedade atenda não apenas os interesses do proprietário, mas também sirva de instrumento para alcançar o bem-estar da coletividade, opera-se internamente o direito de propriedade, como um de seus elementos constitutivos, sem o qual não será plenamente garantida, não se confundindo, portanto, com meras limitações administrativas ao exercício desse direito decorrente do exercício do poder de polícia." ${ }^{27}$

Fica evidente, das sucintas definições acima consignadas, que a função social da propriedade se constitui em um dever imposto à propriedade no sentido de que mesma venha trazer benefícios à sociedade, e não só a seu titular. Em sendo assim, cabe ao Poder Público intervir na propriedade tendo em vista

25. Celso Antônio Bandeira de Mello entende que esse princípio, juntamente com o princípio da indisponibilidade do interesse público, são os princípios basilares do regime jurídico administrativo, no qual todos os outros princípios desse regime são uma decorrência desses dois. Curso de direito administrativo. 25. ed. 2. tir. São Paulo: Malheiros, 2008. p. 69.

26. Silva, José Afonso da. Curso de direito constitucional positivo. São Paulo: Ed. RT, 1991. p. 251.

27. Figueiredo, Guilherme José Purvin de. Desapropriações ambientais na Lei n. 9.985/2000. In: Benjamim, Antonio Herman V. (coord.). Direito ambiental das áreas protegidas: o regime jurídico das unidades de conservação. Rio de Janeiro: Forense Universitária, 2001. p. 471. 
o atendimento dos interesses mais gerais da sociedade; o que ocorre através da utilização do procedimento da desapropriação. Pode-se dizer que este se constitui o modo mais agressivo de intervenção do Estado na propriedade privada, no qual, em virtude de atender ao interesse social e à utilidade pública ou necessidade pública, o Estado toma para si a propriedade do particular, originariamente, mediante indenização prévia e justa. Esse instituto se encontra previsto no art. 5. $^{\circ}, \mathrm{XXIV}$, da CF/1988, que assim dispõe: "a lei estabelecerá o procedimento para desapropriação por necessidade ou utilidade pública, ou por interesse social, mediante justa e prévia indenização em dinheiro, ressalvados os casos previstos nesta Constituição".

No sistema jurídico brasileiro o instituto da desapropriação possui três espécies distintas: por interesse social e por utilidade pública ou necessidade pública.

Conforme Miguel Seabra Fagundes, ${ }^{28}$ a necessidade pública existe "se a Administração está diante de um problema inadiável e premente, isto é, que não pode ser removido, nem procrastinado, e para cuja solução é indispensável incorporar, no domínio do Estado, o bem particular". Assim, a utilidade pública se configura "quando a utilização da propriedade privada é conveniente e vantajosa ao interesse coletivo, mas não constitui um imperativo irremovível”. E o interesse social 29 "quando o Estado esteja diante dos chamados problemas sociais, isto é, daqueles diretamente atinentes às camadas mais pobres da população e à massa do povo em geral, concernentes à melhoria nas condições de vida, à mais equitativa distribuição da riqueza, à atenuação das desigualdade em sociedade".

No entanto, embora a Constituição preveja estas três espécies de desapropriação, a legislação infraconstitucional só prevê a desapropriação por interesse social e por utilidade pública.

A desapropriação por necessidade pública era prevista no art. $590, \S 1 .^{\circ}$, do CC/1916, o qual foi abarcado pelo Dec.-lei 3.365/1941, cuja disposição versa sobre as desapropriações em geral e especificamente sobre a por utilidade pública. Ou seja, a desapropriação por necessidade pública agora consiste em uma das espécies da desapropriação por utilidade pública. Observe-se que a norma que disciplina o procedimento de desapropriação por necessidade pública precede, em quase meio século, a Constituição Federal e, muito mais que isso, o Estatuto da Cidade.

28. O controle dos atos administrativos pelo Poder Judiciário. 8. ed. Rio de Janeiro: Forense, 2010. p. 404 e ss.

29. A desapropriação por interesse social é regulada pela Lei 4.132, de 10.09.1962. 
Ademais, quanto à desapropriação por interesse social, a Constituição a prevê em três dispositivos diversos, correspondendo cada um a diferente legislação ordinária. São eles: (a) o art. 5. $^{\circ}$ XXIV, da CF/1988, disciplinado pela Lei 4.132/1962, cujo art. 2. ${ }^{\circ}$ dispõe sobre os casos de interesse social; (b) o art. 182, $\S 4 .^{\circ}$, da CF/1988 prevê o cabimento quando se tratar de solo urbano não edificado, subutilizado ou não utilizado e desde que já adotadas, sem resultado, as medidas previstas nos incs. I e II do referido parágrafo (parcelamento e edificação compulsórios e imposto predial e territorial urbano progressivo no tempo). Essa desapropriação é de caráter sancionatório e cuida de hipótese nova de desapropriação cujo objetivo é atender à função social da propriedade expressa no plano diretor da cidade (Lei 10.257/2001); ${ }^{30}$ e (c) art. 184 da CF/1988 prevê a desapropriação por interesse social, para fins de reforma agrária e que objetiva assegurar a função social da propriedade rural; estando disciplinada na LC 76/1993. A respeito desse tipo de desapropriação, podemos dizer ser a mesma é muito pouco utilizada pelo Poder Público; o que se coloca em contradição com as grandes necessidades de moradia da população de interesse social no Brasil e as imposições que se colocam, especialmente a partir do Estatuto da Cidade, no tocante ao cumprimento da função social da propriedade urbana.

Com relação ao instituto da desapropriação, necessário ainda serem consideradas as suas características; quais sejam:

a) Necessidade de um procedimento administrativo. A desapropriação não pode ser feita sem a observância do devido processo legal, ${ }^{31}$ devendo ser observado o contraditório e a ampla defesa. ${ }^{32} \mathrm{O}$ procedimento expropriatório garantirá maior transparência à atuação estatal, possibilitando a defesa do indivíduo e inibindo condutas arbitrárias;

30. Ressalte-se que na desapropriação por descumprimento da função social da propriedade urbana a indenização será em títulos da dívida pública, cuja emissão deve ser previamente aprovada pelo Senado Federal, com prazo de resgate de até 10 anos, em parcelas anuais, iguais e sucessivas, asseguradas o valor real da indenização e os juros legais. E no caso da desapropriação para fins da reforma agrária, a indenização será prévia, justa e em títulos da dívida agrária, com a cláusula de preservação do valor real, resgatáveis no prazo de 20 anos, a partir do segundo ano de sua emissão, e cuja utilização será definida em lei. Há aqui uma ressalva que não consta na hipótese anterior: as benfeitorias úteis e necessárias serão indenizadas em dinheiro.

31. A Constituição Federal dispõe em seu art. $5 .^{\circ}$, LIV, que "ninguém será privado da sua liberdade ou de seus bens sem o devido processo legal".

32. O art. 5. ${ }^{\circ}, \mathrm{LV}$, da CF/1988 dispõe que "aos litigantes, em processo judicial ou administrativo, e aos acusados em geral são assegurados o contraditório e ampla defesa, com os meios e recursos a ela inerentes". 
b) Indenização prévia, justa e em dinheiro. A necessidade imposta pela Constituição de a desapropriação ser prévia, justa e em dinheiro decorre da necessidade de o ente público não expropriar a propriedade do cidadão antes de lhe pagar aquilo que lhe é devido; obrigando-o a restituir o particular integralmente dos seus bens expropriados e evitando o abuso de poder.

Consignados os aspectos gerais pertinentes ao instituto da desapropriação, cabe enveredar sobre duas questões bastante atuais e que derivam de uma abordagem constitucional do instituto, quais sejam: a desapropriação da posse e a justa indenização.

\section{DA DESAPROPRIAÇÃO DA POSSE: UMA POSSIBILIDADE EM NOSSO SISTEMA JURÍDICO}

Como vimos, o objeto da desapropriação é a perda de um bem, a transferência compulsória da esfera do particular para a esfera do Poder Público. ${ }^{33}$ Com a desapropriação o particular perde a titularidade do bem, passando este à propriedade do Poder Público. Dessa forma, o instituto ora estudado possui a natureza jurídica de aquisição originária da propriedade, cujos efeitos são a irreversibilidade da transferência e a extinção de direitos reais de terceiro sobre a coisa.

Contudo, apesar de inicialmente, e em regra, a desapropriação só se dar sobre o domínio da propriedade, na atualidade já vem se permitindo considerar a posse como bem a também ser objeto de desapropriação. Isso porque o tempo para o Direito gera direitos: não obstante o lapso temporal ser um fato social, o seu decurso pode gerar efeitos na área jurídica, tornando-se, portanto, em fato jurídico. É nesse sentido - surgimento de efeitos jurídicos em virtude do lapso temporal - que Oswaldo Aranha Bandeira de Mello ${ }^{34}$ afirma "o decurso de certo lapso de tempo acarreta efeitos jurídicos de relevo, pois através dele se pode adquirir ou perder direitos. Em consequência, surgem os institutos da prescrição extintiva e aquisitiva e da extinção e decadência de direitos".

No caso da posse toma-se como exemplo o entendimento da jurisprudência majoritária no sentido de que a sentença de usucapião é meramente declara-

33. Miguel Seabra Fagundes afirma que "não implica, a rigor, extinguir o direito de propriedade, mas leva à substituição forçada do seu objeto. Converte-o via de regra, em dinheiro". Op. cit., p. 399.

34. Princípios gerais do direito administrativo. 3. ed. São Paulo: Malheiros, 2007. vol. I, p. 463. 
tória de direito, ${ }^{35}$ e não constitutiva; onde a constituição do direito se dá em virtude da obediência ao lapso temporal prevista no Direito.

Assim, podemos entender que, através do tempo, a posse gera direitos que não podem deixar de ser respeitados pelo Poder Público. Ora, se a posse com o tempo faz com que o posseiro adquira o direito de nela permanecer sem poder ser importunado por terceiros, inclusive o dono da propriedade (o detentor do domínio), porque seria diferente quando o Poder Público estivesse no outro polo?

Ademais, Jefferson Carús Guedes ${ }^{36}$ entende que os pressupostos norteadores da desapropriação de um bem e, por conseguinte, da sua indenização são três: (a) a comercialidade; (b) o seu valor econômico; e (c) o interesse à consecução de política estatal. E quando a posse se integra, se confunde com o direito de propriedade ao ponto de possuir esses pressupostos, é imperioso a sua observância na desapropriação.

Por outro lado, registra-se que o STJ também entende no sentido da possibilidade da desapropriação da posse, não podendo o Poder Público deixar de observá-la no ato expropriatório. É o que podemos inferir dos seguintes julgamentos:

"O expropriado que detém apenas a posse do imóvel tem direito a receber a correspondente indenização" (REsp 1.118.854/SP, 2. ${ }^{a}$ T., j. 13.10.2009, rel. Min. Eliana Calmon, DJe 28.10.2009).

"Administrativo - Desapropriação indireta - Posse - Indenização - Desnecessidade de provar a propriedade.

I - Configura-se desapropriação indireta, quando o Estado, após imitir agricultor na posse de gleba rural, expulsa-o sumariamente, invadindo o imóvel e se apropriando de acessões e benfeitorias implantadas pelos possuidores.

35. "Civil e processual civil. Julgamento extra petita. Inocorrência. Ação reivindicatória. Título de propriedade. Sentença de usucapião. Natureza jurídica (declaratória). Forma de aquisição originária. Finalidade do registro no cartório de imóveis. Publicidade e direito de dispor do usucapiente. Recurso desprovido. (...) 3. A sentença proferida no processo de usucapião (art. 941 do CPC) possui natureza meramente declaratória (e não constitutiva), pois apenas reconhece, com oponibilidade erga omnes, um direito já existente com a posse ad usucapionem, exalando, por isso mesmo, efeitos ex tunc. O efeito retroativo da sentença se dá desde a consumação da prescrição aquisitiva" (REsp 118.360/SP, 3. ${ }^{a}$ T., j. 16.12.2010, rel. Min. Vasco Della Giustina, DJe 02.02.2011). Nesse mesmo sentido AgRg no Ag 1.319.516/MG; REsp 716.753/RS e REsp 332.880/DF.

36. Desapropriação da posse no direito brasileiro. Revista de Ciências Jurídicas e Sociais, vol. 1, n. 1, p. 58. 
II - Não faz sentido exigir de quem pretende ressarcimento por desapropriação indireta de posse, a prova de propriedade" (REsp 184.762/PR, 1. ${ }^{a}$ T., j. 16.12.1999, rel. Min. Humberto Gomes de Barros).

"Administrativo - Desapropriação - Ação proposta contra possuidor - Indenização - Levantamento - Promitente comprador - Súmula 84.

- Se o expropriante propõe ação contra o possuidor, é porque não queria desapropriar o domínio, mas, simplesmente, a posse.

- O possuidor, titular de promessa de compra e venda relativa a imóvel desapropriado, tem direito ao levantamento da indenização pelo desaparecimento de sua posse. Aplica-se à hipótese, o princípio consagrado na Súmula 84" (REsp 29.066/SP, 1. ${ }^{a}$ T., j. 13.12.1993, rel. Min. César Asfor Rocha).

Disso pode-se afirmar que, ainda que o reconhecimento da posse dependa de cada caso concreto, não podemos nos furtar a afirmar a possibilidade de desapropriação da posse em nosso sistema jurídico, devendo, portanto, ser respeitado o direito à indenização que possui o posseiro nos casos de desapropriação por parte do Poder Público.

\section{A JUSTA INDENIZAÇÃO: DA INSUFICIÊNCIA DO CRITÉRIO ESTRITAMENTE MONETÁRIO}

Como vimos, nos termos postos pela Carta Magna de 1988, a indenização decorrente da desapropriação deve ser prévia e justa.

Quanto ao primeiro requisito, nenhuma dúvida resta, vez que prévia significa ser anterior à consumação. ${ }^{37}$ Mas, qual seria o significado, a teleologia, da denominação "justa" de que trata a Constituição Federal?

Nos termos postos pela doutrina e jurisprudência majoritária, considera-se como justa aquela indenização que visa reembolsar o cidadão do valor do seu bem (patrimônio material desapropriado) com base nos valores mercadológicos.

Gasparini $^{38}$ afirma que justa indenização é aquela:

“(...) paga ao expropriado e que mantém inalterável seu patrimônio. Antes e depois da expropriação tem-se, em valor, o mesmo montante, idêntico patrimônio. Com a desapropriação esse montante não se altera. A quantidade patrimonial é a mesma, embora tenha variado a composição dos bens."

37. Gasparini, Diógenes. Direito administrativo. 16. ed. São Paulo: Saraiva, 2011. p. 903.

38. Idem, ibidem. 
Nesse mesmo sentido é o entendimento de José dos Santos Carvalho Filho ${ }^{39}$ e Celso Antônio Bandeira de Mello. ${ }^{40}$ Este último afirma que a justa indenização "é aquela que corresponde real e efetivamente ao valor do bem expropriado, ou seja, aquela cuja importância deixe o expropriado absolutamente indene, sem prejuízo algum em seu patrimônio".

A jurisprudência não é diferente: o seu entendimento se coaduna perfeitamente com a doutrina. Vejamos:

"Constitucional e administrativo. Desapropriação. Utilidade pública. Intimação da perícia: Ausência de nulidade. Imóvel urbano. Justo preço. Laudo oficial contemporâneo ao apossamento preliminar. Equidistância dos interesses das partes. Juros compensatórios. Juros moratórios. Honorários advocatícios. Correção monetária (...). 2. O valor da justa indenização deve corresponder ao preço de mercado do imóvel à época da imissão, uma vez que este é o momento em que o expropriado sofre a efetiva perda de seu patrimônio" (destacamos) (TRF-1. ${ }^{a}$ Reg., Ac 922020044013800, 3. ${ }^{a}$ T., Des. Carlos Olavo, DJ 29.04.2011, p. 119).

"Administrativo. Desapropriação por interesse social para fins de reforma agrária. Lei 8.629/1993 e LC 76/1993. Valor da terra nua e benfeitorias. Justa indenização. 1. Os valores apurados no laudo administrativo quanto à terra nua e acessões naturais atendem à exigência constitucional da justa indenização, prevista no art. 5. ${ }^{\circ}$, XXIV, da Constituição da República Federativa do Brasil e na Lei 8.629/1993, art. 12, pois refletem convenientemente a realidade imobiliária da região. 2. A justa indenização é aquela que reflete o preço atual de mercado do imóvel em sua totalidade, aí incluídas as terras e acessões naturais, matas e florestas e as benfeitorias indenizáveis" (TRF-1. ${ }^{\text {a }}$ Reg., 4. ${ }^{\text {a }}$ T., Ac 226020004013600 , Des. Hilton Queiroz, DJ 03.09.2004, p. 17).

O entendimento é que deve ser pago o valor necessário para recompor integralmente o patrimônio expropriado, de forma a não haver redução para o proprietário. No cálculo da indenização devem ser incluídas as seguintes parcelas: (a) o valor do bem expropriado, com todas as benfeitorias que já existiam no imóvel antes do ato expropriatório; quanto às benfeitorias feitas posteriormente, serão pagas as benfeitorias necessárias; as úteis somente se realizadas com autorização do expropriante (art. 26 do Dec.-lei 3.365/1941); ${ }^{41}$ (b) os lucros cessantes e os danos emergentes; (c) os juros compensatórios, em

39. Manual de direito administrativo. 21. ed. Rio de Janeiro: Lumen Juris, 2009. p. 809.

40. Op. cit., p. 382-383.

41. A respeito das construções feitas posteriormente, ainda que com licença concedida pelo Município, não são incluídas no valor da indenização, conforme a Súmula 23 do STF. 
caso de ter havido imissão provisória na posse, computando-se a partir dessa imissão; a sua base de cálculo é a diferença entre a oferta inicial do Poder Público e o valor da indenização; ${ }^{42}$ (c) os juros moratórios também são incidentes sobre a mesma base de calculo, no montante de $6 \%$ ao ano, a partir de $1 \%$ de janeiro do exercício seguinte em que o pagamento deveria ter sido feito; (d) Os honorários advocatícios, calculados sobre a diferença entre a oferta inicial e o valor da indenização, acrescido de juros moratórios e compensatórios; (e) custas e despesas judiciais e (f) correção monetária. ${ }^{43-44}$

Observemos que a questão patrimonial, assentada em critérios monetários, possui ampla atenção e consideração por parte da doutrina e jurisprudência. Porém, uma coisa vem passando despercebida nessa análise e que, diante de todo um novo regramento concedido pelo ordenamento jurídico ao direito à moradia e ao direito à cidade, não pode ser ignorado. Estamos aqui a tratar da perda que ocorre do patrimônio moral constituído a partir do exercício do direito à moradia, durante um longo período, em determinado local da cidade, a ser objeto do desejo desapropriatório por parte da Administração Pública.

Sob a compreensão fundamental de que "o tempo gera direitos", é indiscutível que o morar durante um determinado período em determinado local na cidade gera direitos aos seus moradores. É o caso da população residente em área reconhecida como de interesse social nos planos diretores municipais (as zonas e as áreas especiais de interesse social - Zeis e Aeis). Tais zonas/áreas re-

42. Sobre esses juros, existem duas Súmulas do STF: a Súmula 164, "no processo de desapropriação, são devidos juros compensatórios desde a antecipada imissão na posse, ordenada pelo juiz, por motivo de urgência"; e a Súmula 618, segundo a qual, "na desapropriação, direta ou indireta, a taxa de juros compensatórios é de 12\% (doze por cento) ao ano". O STJ, pela Súmula 69, fixou o entendimento de que na desapropriação direta, "os juros compensatórios são devidos desde a antecipada imissão na posse e, na desapropriação indireta, a parte da efetiva ocupação do imóvel". Ou seja, os juros compensatórios são devidos, na desapropriação direta, desde a antecipação da imissão na posse, e na antecipação indireta, a partir da efetiva ocupação na posse.

43. Súmula 561 do STF: "em desapropriação, é devida a correção monetária até a data do efetivo pagamento da indenização, devendo proceder-se à atualização de cálculo, ainda que por mais de uma vez".

44. Quanto à desapropriação na área urbana por desatendimento da função social da propriedade, a Lei 10.257/2001 estabelece, no § $2 .^{\circ}$ do art. $8 .^{\circ}$, que "o valor real da indenização: I - refletirá o valor base do cálculo do IPTU, descontando o montante incorporado em função das obras realizadas pelo Poder Público na área onde o mesmo se localiza após a notificação de que trata o $§ 2 .^{\circ}$ do art. $5 .^{\circ}$ desta Lei; II - não computará expectativas de ganhos, lucros cessantes e juros compensatórios". 
velam "o reconhecimento do dos assentamentos humanos existentes na cidade, em sua diversidade, e sua inclusão no zoneamento da cidade" ${ }^{45}$ Através da instituição de Zeis/Aeis se permite "o estabelecimento de um regime jurídico especial de urbanização e regularização fundiária, dando concretude ao novo paradigma inaugurado pela Constituição Federal de 1988 e consolidado pelo Estatuto da Cidade no tratamento dos assentamentos informais". ${ }^{46}$

Importa destacar que essas áreas geralmente se encontram inseridas na cidade, sendo dotadas da infraestrutura e situadas próximas aos centros de comércio e serviços; o que garante a seus habitantes o gozo de alguns direitos que compõe o direito a cidades sustentáveis (art. 2. ${ }^{\circ}$, I, do Estatuto da Cidade), entendido como "o direito à terra urbana, à moradia, ao saneamento ambiental, à infraestrutura urbana, ao transporte e aos serviços públicos, ao trabalho e ao lazer, para as presentes e futuras gerações".

Assim, podemos dizer que através da instituição dessas zonas/áreas especiais se possibilita a efetivação/concretização do direito fundamental à moradia e o direito à cidade, por parte de uma parcela da população excluída do mercado formal de habitação.

Por outro lado, não se constitui novidade a constatação de que, sobretudo nos ambientes de moradia da população de baixa renda (geralmente constituídos através de ocupação possessória), as relações entre os habitantes se entrelaçam por manifestações sociais de apoio e solidariedade entre vizinhos, pertencentes ao mesmo lugar e vivendo sob as mesmas condições. Em termos bem claros, para facilitar a compreensão: é a vizinha que constantemente cuida dos filhos da outra para que a mesma possa trabalhar; são os vizinhos que se apoiam e se amparam nos momentos de doença e de desemprego; são os moradores que fazem acertos com os donos das mercearias do lugar para comprar "fiado" e pagar apenas no final do mês ou quando "o dinheiro entrar". Ainda que uma série de exemplos pudessem aqui ser compilados para traduzir as relações de vizinhanças que se estabelecem nas comunidades (especialmente as de interesse social), importa no momento considerar que nesses locais existem formas de sociabilidade específicas - um complexo de relações sociais - que se desenvolvem a partir dos locais de moradia dessa população e que refletem, em última análise, uma falta do Estado na promoção de ações básicas e essenciais

45. Duarte, Marise Costa de Souza. Op. cit., p. 110.

46. Romeiro, Paulo Somlanyi. Zonas especiais de interesse social: materialização de um novo paradigma no tratamento dos assentamentos informais ocupados por população de baixa renda. Dissertação de Mestrado, São Paulo, PUC, 2010, p. 114. 
para tal população (disponibilização de creches em locais próximo à moradia, de serviços de saúde acessíveis a todos, de acesso ao crédito aos que não possuem empregos formais etc.).

Desse modo, podemos dizer que, em razão de uma especial proteção jurídica conferida ao direito à moradia da população de interesse social (que depende de ações do Estado para atendimento de suas necessidades essenciais, na qual se coloca a moradia) e considerando as relações sociais próprias que geralmente se estabelecem nessas áreas (que muitas vezes vem suprir a omissão estatal), essa parcela da população possuirá um (determinado) patrimônio moral, que não poderá ser ignorado quando se trata de fixar a indenização por desapropriação em casos de utilidade pública. Nesse sentido, nos parece perfeitamente defensável o entendimento de que apenas o critério monetário não pode ser utilizado para a fixação de indenização quando se trata de desapropriação por utilidade pública no caso da população de interesse social. Disso decorre nossa compreensão de que o conceito constitucional de justa indenização deverá levar em conta as condições sociais dos expropriados (especialmente nos casos de desapropriação da posse) e o contexto em que ocorre a desapropriação por utilidade pública, como se constata no caso dos megaeventos esportivos.

\section{UMA NOVA E NECESSÁRIA VISÃO DA DESAPROPRIAÇÃO POR UTILIDADE PÚBLICA (EM MEGAEVENTOS ESPORTIVOS) E A INAPLICABILIDADE DO DEC.- LEI 3.365/1941}

Vistas algumas questões essenciais quando se pretende analisar o instituto da desapropriação, a partir de uma abordagem constitucional e infraconstitucional (com enfoque no Estatuto da Cidade), e onde os direitos fundamentais estão no centro do ordenamento jurídico suscitando deveres objetivos aos entes estatais; adentramos na última etapa do texto, onde encaminhamos nossa análise para as desapropriações por utilidade pública no caso de projetos voltados a megaeventos esportivos, com maior enfoque às áreas ocupadas por população de baixa renda.

Como bem lembra Raquel Rolnik, na década de 90 do século XX, "tornou-se hegemônica a prática de organização de megaeventos como componentes do planejamento urbano estratégico, com vistas a melhorar a posição destas cidades na economia globalizada". Podemos dizer que durante o século XX os jogos olímpicos e outros eventos esportivos passaram de uma situação em que poucas marcas deixavam na paisagem urbana, para outra em que passa- 
ram a influenciar fortemente nos processos de transformação urbana, ${ }^{47}$ senão conduzi-lo.

Podemos dizer que desde os Jogos Olímpicos de Barcelona (1992) a realização de megaeventos esportivos, organizados por poderosas organizações privadas (Comitê Olímpico Internacional - COI e Federación Internacionale de Football Association - Fifa), vem trazendo substanciais transformações nas cidades onde se realizam e na vida de seus habitantes.

Ainda que a realização de megaeventos sirva habitualmente como catalisador para o início e aplicação de planos de desenvolvimento de moradia nas cidades anfitriãs, às quais se destinam maiores investimentos públicos e privados (especialmente ao setor de construção) ${ }_{,}^{48}$ com incremento nos empregos e na disponibilidade de unidades habitacionais; também pode ocorrer que os ganhos desses eventos esportivos se limitem ao setor privado, sem que a sociedade, como um todo, possa usufruir do legado positivo que o mesmo possa trazer. E o pior: que a preparação e a realização de tais eventos ignorem os direitos fundamentais que possuem a população de baixa renda, especialmente o direito à moradia digna e adequada.

No Brasil essa situação passa a ficar mais visível no momento em que nossas cidades se organizam para a realização da Copa do Mundo (2014) e das Olimpíadas do Rio (2016). Ainda que a realização dos Jogos Panamericanos (2007), no Rio de Janeiro, já tenha revelado uma face (cruel) de desrespeito aos direitos de famílias de baixa renda (sumariamente "retiradas" de seus locais de moradia para construção de obras necessárias àquele evento esportivo), é na preparação das cidades-sedes para os eventos de 2014 e de 2016, que começa a se revelar o quanto tais eventos podem se tornar "rolos compressores" sob direitos fundamentais postos na Carta Magna brasileira, especialmente o direito à moradia da população de baixa renda.

Trazendo o foco para nosso objeto de estudo, ${ }^{49}$ se observa que, em razão da premência na execução dos projetos públicos relativos àqueles megaeventos (com enfoque para os estádios e as obras de mobilidade para a Copa de 2014), os Poderes Públicos vem praticamente ignorando seu dever estatal de proteção

47. Tudo como lembra Raquel Rolnik. A questão dos megaeventos é debatida na ONU. Disponível em: [http://raquelrolnik.files.wordpress.com/2010/11/mega_eventos_ portugues1.pdf]. Acesso em: 08.10.2010.

48. Idem.

49. Ainda que se pudesse elencar uma série de fatos ligados à preparação do Brasil para a Copa de 2014, que demonstram o desprezo de seus organizadores com os direitos fundamentais consignados na Constituição Federal. 
e promoção do direito à moradia da população de interesse social, fazendo vistas grossas às regras que amparam esse direito e o direito à cidade sustentável que possui essa população, para quem o princípio da dignidade humana é, na maioria das vezes, totalmente desconsiderado.

Tal constatação advém da percepção de que, por parte do Poder Público em geral, tem-se a ideia de que as famílias de baixa renda que ocupam informalmente as áreas necessárias à realização daquelas obras devem se "contentar" com o valor oferecido para desocupação de seus imóveis, valor geralmente calculado sem considerar a valorização imobiliária que aquela área passou a ter por estar inserida nos projetos voltados àqueles megaeventos. Valor que ignora o patrimônio moral daquelas populações, valor que não considera (voluntariamente ou não) que aquela população inserida em zonas/áreas de interesse social possui o direito à moradia digna e adequada naquele local (muitas vezes ocupado há anos) e o direito à cidade sustentável (nos termos do art. 2. ${ }^{\circ}$, I, do Estatuto da Cidade), direitos que reúnem um plexo de direitos essenciais àquelas pessoas (como o direito à terra urbana, à infraestrutura urbana, aos serviços públicos e ao trabalho, para falar apenas de alguns) cujo exercício se possibilita naquele local, por sua proximidade com os centros de comércio e de serviços. Como consequência, tem-se geralmente a expulsão daquela população para áreas distantes (as únicas onde o valor pago a título de indenização possibilita acessar um novo imóvel), carentes de infraestrutura e de serviços públicos que possibilitem o gozo do direito à moradia digna e adequada e o direito à cidade, além dos outros direitos sociais. Tudo isso em evidente afronta ao princípio da dignidade da pessoa humana, um dos fundamentos da República Federativa do Brasil, conforme o artigo que inaugura nossa Carta Magna.

Por outro lado, merece enfoque especial o fato de que, quanto à desapropriação por utilidade pública, mesmo após a Constituição Federal de 1988 e o Estatuto da Cidade, a normatização aplicada (pela ausência de outra) vem sendo a inserida no Dec.-lei 3.365/1941, elaborado sob a égide da Constituição de 1937, e no qual o Direito era visto de forma meramente patrimonialista.

Ainda que se pudesse realizar uma ampla análise daquele decreto-lei, sob a égide da Constituição Federal de $1988,{ }^{50}$ a partir da qual se instalou no país um plexo de direitos e regras de caráter democrático, que não se coadunam com o

50. Inclusive questionando sua constitucionalidade (também do ponto de vista formal) em face do que dispõe o inc. XXIV do art. $5 .^{\circ}$ da CF/1988, in verbis: "a lei estabelecerá o procedimento para desapropriação por necessidade ou utilidade pública, ou por interesse social, mediante justa e prévia indenização em dinheiro, ressalvados os casos previstos nesta Constituição" (destacamos). 
sistema anterior, em face das limitações desse texto evidenciaremos apenas alguns aspectos que revelam essa constatação. Vejamos algumas regras contidas naquele decreto-lei:

"Art. $7 .^{\circ}$ Declarada a utilidade pública, ficam as autoridades administrativas autorizadas a penetrar nos prédios compreendidos na declaração, podendo recorrer, em caso de oposição, ao auxílio de força policial.

Àquele que for molestado por excesso ou abuso de poder, cabe indenização por perdas e danos, sem prejuízo da ação penal.

(...)

Art. 9. ${ }^{\circ}$ Ao Poder Judiciário é vedado, no processo de desapropriação, decidir se se verificam ou não os casos de utilidade pública" (destacamos).

A partir de uma simples observação apenas dessas duas regras, podemos, de pronto, constatar que os amplos poderes concedidos ao Executivo, nos casos de desapropriação por utilidade pública, não estão amparados pela ordem jurídica em vigor. Observa-se que, conforme o art. 7. ${ }^{\circ}$ do Dec.-lei 3.365/1941, o expropriado pode ser sumariamente expulso de seu imóvel, inclusive submetendo-se à força policial, tão e somente a partir da declaração de utilidade pública do bem. E ainda: sendo vedada qualquer apreciação judicial quanto à verificação ou não dos casos de utilidade pública. Lembremos o que nos diz a Constituição Federal de 1988 no âmbito dos direitos e garantias fundamentais:

"Art. 5. ${ }^{\circ}(\ldots)$

III - ninguém será submetido a tortura nem a tratamento desumano ou degradante;

(...)

XXXV - a lei não excluirá da apreciação do Poder Judiciário lesão ou ameaça a direito;

(...)

LIV - ninguém será privado da liberdade ou de seus bens sem o devido processo legal;

LV - aos litigantes, em processo judicial ou administrativo, e aos acusados em geral são assegurados o contraditório e ampla defesa, com os meios e recursos a ela inerentes;

(..)."

Ora, no momento em que os expropriados são sumariamente retirados de seu imóvel, sem qualquer oportunidade de contraditório e defesa, e sem que caiba qualquer apreciação, por parte do Judiciário, é evidente que o Dec.-lei 3.365/1941 rompe absolutamente a ordem constitucional instituída para pro- 
teção dos direitos e garantias fundamentais. Essa situação se agrava quando se observa que, em se tratando dos megaeventos esportivos, também são totalmente ignoradas as normas de planejamento urbano existentes. Lembremos, neste tópico, o que diz a Constituição Federal de 1988:

"Art. 182. A política de desenvolvimento urbano, executada pelo Poder Público municipal, conforme diretrizes gerais fixadas em lei, tem por objetivo ordenar o pleno desenvolvimento das funções sociais da cidade e garantir o bem-estar de seus habitantes.

$\S 11^{\circ}$ O plano diretor, aprovado pela Câmara Municipal, obrigatório para cidades com mais de vinte mil habitantes, é o instrumento básico da política de desenvolvimento e de expansão urbana.

$\S 2 .^{\circ}$ A propriedade urbana cumpre sua função social quando atende às exigências fundamentais de ordenação da cidade expressas no plano diretor.

(...)" (destacamos).

Lembremos que, na regulamentação do capítulo da política urbana na Carta Magna, veio o Estatuto da Cidade estabelecer "normas de ordem pública e interesse social que regulam o uso da propriedade urbana em prol do bem coletivo, da segurança e do bem-estar dos cidadãos, bem como do equilíbrio ambiental" (parágrafo único do seu art. 1. $^{\circ}$ ); prescrevendo que a política urbana tem por objetivo ordenar o pleno desenvolvimento das funções sociais da cidade e da propriedade urbana, mediante diretrizes gerais ali estabelecidas.

Contudo, o que se constata é que os projetos e obras referentes aos megaeventos esportivos, em geral, não são elaborados e executados sob a égide do que prescreve a Constituição Federal e o Estatuto da Cidade; sendo em geral obras pontuais (visando o atendimento de interesses de funcionalidade e operacionalidade dos eventos, em favor dos visitantes ocasionais), desconectadas das regras de planejamento urbano instituídas para a cidade que, em geral, são construídas mediante (obrigatório) processo participativo. ${ }^{51}$

Diante de tudo isso, se encontra um caminho totalmente aberto para que se questione se a desapropriação em tais casos se assenta em seu objetivo fundamental: fazer cumprir a função social da propriedade.

Tais constatações se aliam ao entendimento quanto à necessária rediscussão do conceito constitucional de justa indenização, nos casos de desapropriação

51. O caso de Natal/RN é um bom exemplo desse fato, pois se constata que as obras de mobilidade urbana em andamento para a Copa de 2014 não estão conectadas com a política de mobilidade urbana instituída no plano diretor de 2007. 
por utilidade pública (tratando-se de megaeventos esportivos), especialmente quando se trata da população de interesse social.

\section{CONCLUSÃO}

Em face de todo o exposto, consideramos possível, no âmbito da discussão doutrinária envolvendo o tema dos direitos fundamentais, propor e promover uma rediscussão do termo justa indenização em nosso ordenamento jurídico, especialmente quando se trata de desapropriação por utilidade pública (tendo como foco o caso dos megaeventos esportivos, eventos de natureza privada onde majoritariamente se utilizarão vultosas verbas públicas para sua viabilização) e considerando, de modo específico, os direitos de uma população (de interesse social) alijada do mercado imobiliário formal, para a qual o gozo dos direitos urbanos, donde se destaca o direito à moradia e o direito à cidade sustentável (com todos os direitos que lhe são inerentes nos termos do art. 2. ${ }^{\circ}$ do Estatuto da Cidade) se coloca pressuposto fundamental para a promoção de sua dignidade humana. Nesse sentido, se formulam as seguintes conclusões articuladas:

1) O regime jurídico que ampara o direito fundamental à moradia no ordenamento jurídico brasileiro, que vincula toda a atuação do Poder Público (inclusive quando se trata de projetos e obras referentes a megaeventos esportivos) impede que pessoas sejam despojadas sumariamente de seus locais de moradia.

2) A proteção ao direito à moradia (digna e adequada) está intrinsecamente ligada ao direito à cidade (direito materialmente constitucional e expressamente consagrado no Estatuto da Cidade); o que expressa a compreensão de que esse direito não significa apenas o acesso a uma unidade habitacional, mas o acesso a todos os benefícios públicos que a cidade oferece a seus habitantes, independente de sua classe social.

3) Em razão disso, no âmbito do procedimento da desapropriação (onde deve ser observado o devido processo legal) há que ser respeitado todo o regime jurídico que ampara o direito fundamental à moradia e o direito à cidade, especialmente quando se trata da população de interesse social (que, sem acesso ao mercado imobiliário, se encontra na dependência absoluta das ações estatais). Assim, é no momento do exercício do contraditório e a ampla defesa no procedimento expropriatório que se garantirá maior transparência à atuação estatal, possibilitando a defesa do indivíduo e inibindo condutas arbitrárias que venham afrontar os direitos à moradia digna e adequada e o direito á cidade.

4) Considerando possível, em nosso sistema jurídico, a desapropriação também da posse, é de se compreender que a "justa indenização" (requisito 
constitucional para a desapropriação) não pode ser auferida apenas a partir de critérios patrimoniais; sendo necessário que se seja levado em consideração o patrimônio moral gerado pela moradia decorrente dos anos passados no local e pelas relações de vizinhança adquiridas; compreensão que se pauta nos valores resguardados pela Carta Magna, donde se destaca a dignidade da pessoa humana.

5) Diante do novo regramento especial concedido ao direito à moradia (digna e adequada), pautado em um regime democrático consagrado pela Constituição Federal de 1988, aperfeiçoado pela inserção do direito á cidade no ordenamento jurídico brasileiro, fica evidente que as regras para a desapropriação por utilidade pública constantes no Dec.-lei 3.365/1941 (elaborado sob a égide da Constituição de 1937 e no qual o Direito era visto de forma meramente patrimonialista) não podem ser aplicadas quando vem esse direito fundamental (aliado ao direito à cidade) e a dignidade da pessoa humana.

\section{REFERÊNCIAS}

Bandeira de Mello, Celso Antonio. Curso de direito administrativo. 25. ed. 2. tir. São Paulo: Malheiros, 2008.

Bandeira de Mello, Oswaldo Aranha. Princípios gerais do direito administrativo. 3. ed. São Paulo: Malheiros, 2007. vol. I.

BARROSO, Luis Roberto. O direito constitucional e a efetividade de suas normas: limites e possibilidades da Constituição brasileira. 9. ed. Rio de Janeiro: Renovar, 2009.

Canotilho, José Joaquim Gomes. Tomemos a sério os direitos econômicos, sociais e culturais. Estudos sobre direitos fundamentais. Coimbra: Coimbra Ed., 2004.

Carvalho Filho, José dos Santos. Manual de direito administrativo. 21. ed. Rio de Janeiro: Lumen Juris, 2009.

CORREIA, Fernando Alves. Os direitos fundamentais e sua proteção jurisdicional efectiva. Boletim da Faculdade de Direito da Universidade de Coimbra. vol. LXXIX. Coimbra, 2008.

Dimoulis, Dimitri; Martins, Leonardo. Teoria geral dos direitos fundamentais. 2. ed. São Paulo: Ed. RT, 2008.

Duarte, Marise Costa de Souza. Espaços especiais em Natal (meio ambiente e moradia): um necessário diálogo entre direitos e espaços na perspectiva de proteção aos direitos fundamentais na cidade contemporânea. Tese do Programa de Pós-Graduação em Arquitetura e Urbanismo, Natal, UFRN, 2010.

Espaços especiais urbanos: desafios à efetivação dos direitos ao meio ambiente e moradia. Rio de Janeiro: Letra Capital, 2011. Coleção Metrópoles (Observatório das Metrópoles). 
Ferreira, João Sette Whitaker; Motisuke, Daniela. A efetividade da implementação de zonas especiais de interesse social no quadro habitacional brasileiro: uma avaliação inicial. In: Bueno, Laura Machado de Mello; Cymbalista, Renato (orgs.). Planos diretores municipais: novos conceitos de planejamento territorial. São Paulo: Annablume, 2007.

Figueiredo, Guilherme José Purvin de. Desapropriações ambientais na Lei $\mathrm{n}$. 9.985/2000. In: Benjamin, Antonio Herman V. (coord.). Direito ambiental das áreas protegidas: o regime jurídico das unidades de conservação. Rio de Janeiro: Forense Universitária, 2001.

Gasparini, Diógenes. Direito administrativo. 16. ed. São Paulo: Saraiva, 2011.

Guedes, Jefferson Carús. Desapropriação da posse no direito brasileiro. Revista de Ciências Jurídicas e Sociais. vol. 1. n. 1. p. 58. Umuarama: Unipar, jul.-dez. 1998.

Rolnik, Raquel. A questão dos megaeventos é debatida na ONU. Disponível em [http://raquelrolnik.files.wordpress.com/2010/11/mega_eventos_portugues1.pdf]. Acesso em: 08.10.2010.

Romeiro, Paulo Somlanyi. Zonas especiais de interesse social: materialização de um novo paradigma no tratamento dos assentamentos informais ocupados por população de baixa renda. Dissertação de Mestrado, São Paulo, PUC, 2010.

SARLET, Ingo Wolfgang. A eficácia dos direitos fundamentais. Porto Alegre: Livraria do Advogado, 1998.

O direito fundamental à moradia na Constituição: algumas anotações a respeito de seu contexto, conteúdo, e possível eficácia. Revista Eletrônica sobre a Reforma do Estado (RERE). n. 20. dez.-fev. 2009-2010. Disponível em: [www.direitodoestado.com/revista/RERE-20-DEZEMBRO-2009-INGO-SARLET.pdf]. Acesso em: 26.04.2010.

SAUlE JR., Nelson. O direito à cidade como condição para cidades justas, humanas e democráticas. 2005. Disponível em: [www.polis.org.br]. Acesso em: 07.07.2008.

. O direito à moradia como responsabilidade do Estado brasileiro. In: (org.). Direito à cidade: trilhas legais para o direito à cidades sustentáveis. São Paulo: Max Limonad, 1999.

Seabra Fagundes, Miguel. O controle dos atos administrativos pelo Poder Judiciário. 8. ed. Rio de Janeiro: Forense, 2010.

Silva, José Afonso da. Curso de direito constitucional positivo. São Paulo: Ed. RT, 1991.

SiLva, Vasco Pereira da. Em busca do acto administrativo perdido. Dissertação de Doutoramento em Ciências Jurídico-Políticas na Faculdade de Direito da Universidade Católica Portuguesa. reimp. Coimbra: Livraria Almedina, 1998. 


\section{Pesouisas do Editorial}

\section{Veja também Doutrina}

- Aspectos relevantes da desapropriação por interesse social para fins de reforma agrária - Ação estatal interventiva no domínio privado, de Élio Wanderlei de Siqueira Filho - RT 689/75;

- Desapropriação por interesse social para fins de reforma agrária e a recomposição da condição jurídica do expropriado, de Maria Helena Diniz - RDCl 21/65;

- Desapropriação por utilidade pública: levantamento integral da indenização provisória $\left(\mathrm{LD}, 33, \S 2 .^{\circ}\right)$, de Marcelo Vieira Von Adamek - RDCl 12/155; e

- Direito fundamental de propriedade. Atendimento à função social. Requisitos para desapropriação para fins de reforma agrária. Vícios formais e materiais do processo administrativo. Cabimento de mandado de segurança, de Ives Gandra da Silva Martins e Cláudia Fonseca Morato Pavan - RT 859/127. 